Gynecologic and

Obstetric Investigation
Gynecol Obstet Invest 2009;68:9-18

DOI: 10.1159/000209396
Received: May 22, 2008

Accepted after revision: November 3, 2008

Published online: March 26, 2009

\title{
Syncytin-1 and Glial Cells Missing a: \\ Hypoxia-Induced Deregulated Gene Expression along with Disordered Cell Fusion in Primary Term Human Trophoblasts
}

\author{
C. Wich ${ }^{a, b}$ S. Kausler ${ }^{a} \quad$ J. Dotsch $^{a} \quad$ W. Rascher ${ }^{\text {a }} \quad$ I. Knerr ${ }^{a}$ \\ ${ }^{a}$ Children's and Adolescents' Hospital and b Department of Internal Medicine 1, University of Erlangen-Nuremberg, \\ Erlangen, Germany
}

\section{Key Words}

ASCT2 receptor $\cdot$ Glial cells missing a $\cdot$ Hypoxia $\cdot$

Pre-eclampsia $\cdot$ Syncytin- $1 \cdot$ Trophoblast

\begin{abstract}
Background/Aims: Pre-eclampsia, a major cause of perinatal morbidity, is characterized by alterations in placental oxygen availability and trophoblast differentiation. We investigated how different levels of hypoxia alter the expression of syncytin-1, glial cells missing a (GCMa) and syncytin-1 receptor ASCT2 and affect syncytialization in primary term human trophoblasts. Methods: Cells were incubated at 1, 3, 6 and $21 \% \mathrm{O}_{2}$ for 24,48 and $72 \mathrm{~h}$ with or without cyclic adenosine monophosphate (cAMP). Gene expression was analyzed by real-time PCR. Syncytialization was assessed using $\beta$-human chorionic gonadotropin measurement and desmoplakin immunostaining. Results: Following incubation with CAMP at $21 \% \mathrm{O}_{2}$, peak gene expression of syncytin-1 and GCMa was found after $24 \mathrm{~h}$ along with syncytium formation at $72 \mathrm{~h}$. Conversely, incubation at $1 \% \mathrm{O}_{2}$ led to a time-dependent reduction of GCMa and syncytin-1 at the transcriptional level. Cell fusion occurred at 21 and $6 \% \mathrm{O}_{2}$ and was suppressed at $1 \% \mathrm{O}_{2}$. ASCT2 mRNA levels were preserved at normoxia and downregulated at $1 \% \mathrm{O}_{2}$ after $48 \mathrm{~h}$. Conclusion: Our data support the premise that the expression of GCMa and syncytin-1 precedes syncytialization of trophoblasts, e.g. at $6 \%$
\end{abstract}

$\mathrm{O}_{2}$, which is assumed to resemble physiological conditions. Severe hypoxia is associated with reduced GCMa and syncytin-1 transcripts and altered fusion of primary trophoblasts.

Copyright ๑ 2009 S. Karger AG, Basel

\section{Introduction}

Pre-eclampsia is a serious complication in the second half of pregnancy and is potentially life threatening for both mother and child. It is characterized by arterial hypertension, proteinuria together with renal dysfunction and edema, and other systemic disturbances, which may eventually lead to preterm birth and increased morbidity [1-3]. Generally, symptoms of pre-eclampsia are observed in late pregnancy, but the origin of this disease is a defective placental development in early gestation. Maternal diabetes or hypertension predispose to pre-eclampsia [2]. Chronic hypoxia in the placenta plays an important role in its pathogenesis [4]. A proliferative phenotype of cytotrophoblasts has been described in affected placentas along with a reduced syncytial layer [5]. Moreover, an increased apoptotic rate and shedding of syncytial fragments may eventually lead to an inflammatory response and systemic presentation in the maternal circulation [6]. In the course of this disorder, placental oxygen exchange and metabolic function are considerably disturbed and

\section{KARGER}

Fax +41613061234 E-Mail karger@karger.ch www.karger.com

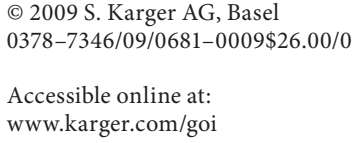

Ina Knerr, $\mathrm{MD}, \mathrm{PhD}$

Kinder- und Jugendklinik, Universität Erlangen-Nürnberg

Loschgestrasse 15

DE-91054 Erlangen (Germany)

Tel. +49 913185 33118, Fax +49913185 33113, E-Mail ina.knerr@uk-erlangen.de 
may cause intrauterine growth restriction. However, although a variety of pathogenic factors have been proposed, the etiology of pre-eclampsia is still not completely understood.

One of the key regulators of human placentogenesis is syncytin-1, which has been identified as the envelope protein of a human endogenous retrovirus family HERV$\mathrm{W}[7,8]$. Syncytin-1 is predominantly expressed within the placenta, and its expression increases throughout gestation [7, 9]. Alteration of syncytin-1 mRNA levels and protein distribution, along with disturbed placental architecture and function, have been found in placental tissues obtained from women with pre-eclampsia or HELLP syndrome, defined by hemolysis, elevated liver enzymes and low platelets [10-13]. Therefore, altered cell-cell fusion events involving differentiated cytotrophoblasts may deteriorate hypoxia in these disorders.

Fusogenic processes can be stimulated in trophoblastic cells by cyclic adenosine monophosphate (cAMP)-dependent pathways such as protein kinase A [14-17]. We have already shown that the protein kinase A pathway acts upstream of syncytin-1 [14]. Mammalian glial cells missing (GCM) proteins orchestrate different developmental pathways in the placenta, for example, and may be involved in pathological contexts such as pre-eclampsia [18].

Generally, cell-cell communication, e.g. between trophoblastic cells, may be facilitated through gap junctions. These are multimeric structures composed of proteins called connexins, which ensure the intercellular exchange of signaling molecules such as cAMP and $\mathrm{Ca}^{2+}[19,20]$. During trophoblastic syncytialization, an increase in gap junction formation occurs, as demonstrated by enhanced staining of connexin 43 between cells [21]. Isolated cytotrophoblasts contain desmosomes at their membranes which can be detected by antibodies to desmoplakin and are found to be reduced in the course of cell-cell fusion $[17,22,23]$.

The dually functioning amino acid transporter and putative syncytin-1 receptor, ASCT2, is located at the basal membrane of the syncytiotrophoblast adjacent to the fetal circulation $[15,24]$. Syncytial fusion and membrane specialization may be accompanied by a decrease in ASCT2 activity [25]. Moreover, ASCT2 can be downregulated at the transcriptional level following incubation with the adenylate cyclase activator forskolin, but produces almost constant mRNA levels after $24 \mathrm{~h}$ in a hypoxic atmosphere $[15,26]$.

Beta-human chorionic gonadotropin ( $\beta$-hCG) and human placental lactogene (hPL) are two major placental protein hormones associated with syncytium formation of trophoblasts. Moreover, $\beta$-hCG secretion and hPL expression are suitable parameters for assessing the endocrine activity of trophoblasts, as opposed to the cytoskeletal protein actin, for example [5].

In this study, we focused firstly on the gene expression pattern of syncytin-1, GCMa and ASCT2 in term human trophoblasts under different hypoxic challenges and incubation periods, and secondly looked at the corresponding cell-cell fusion processes in order to further elucidate the syncytialization processes under different oxygen concentrations in vitro.

\section{Materials and Methods}

\section{Cell Culture}

After approval by the local ethics committee, term placentas of patients who underwent cesarean section were collected for the isolation of primary trophoblasts according to a standard method using trypsin-DNAse I Percoll gradient centrifugation [27, 28]. Cells were cultured in Dulbecco's modified Eagle's medium (Gibco BRL, Karlsruhe, Germany) containing $10 \%$ fetal calf serum. Experiments were carried out in 6-well plates (Nunc, Wiesbaden, Germany). Basically, cAMP agonists such as the adenylate cyclase activator forskolin $(100 \mu \mathrm{M})$ or 8 -Br-cAMP $(150 \mu \mathrm{M})$ were added to drive cellular differentiation. Experiments with unstimulated cells were used for comparison. Incubation was carried out in Thermo Forma cell incubators (Forma Scientific, Marietta, Ohio, USA) under normoxia $\left(\mathrm{O}_{2}\right.$ tension $150 \mathrm{~mm} \mathrm{Hg}, 21 \% \mathrm{O}_{2}, 74 \% \mathrm{~N}_{2}$ and $5 \% \mathrm{CO}_{2}$ at $37^{\circ} \mathrm{C}$ ) and under different hypoxic conditions. Hypoxia was applied for 24, 48 and $72 \mathrm{~h}$ with $1 \% \mathrm{O}_{2}(7 \mathrm{~mm} \mathrm{Hg})$, $3 \% \mathrm{O}_{2}(21 \mathrm{~mm} \mathrm{Hg})$ or $6 \% \mathrm{O}_{2}(43 \mathrm{~mm} \mathrm{Hg})$ and 94,92 and $89 \% \mathrm{~N}_{2}$, respectively, together with $5 \% \mathrm{CO}_{2}$. All experiments were performed in triplicate and were repeated at least 3 times.

Viability Assays, Flow Cytometry and Annexin V/Propidium

Iodide Apoptosis Assay

Cell viability was tested by trypan blue staining and fluorescence-activated cell sorting as reported previously [14, 29]. Briefly, apoptotic cells were detected using fluorescein isothiocyanateconjugated annexin $\mathrm{V}$ and propidium iodide double staining. After stimulation and staining, $10^{5}$ cells were analyzed by flow cytometry (FACS Calibur, Becton-Dickinson, Heidelberg, Germany). Appropriate electronic compensation of the instrument was performed to avoid overlapping of the emission spectra. On average, $10 \%$ cell death was considered acceptable for continuation of experimental procedures.

Molecular Analysis and Real-Time PCR

Total RNA was isolated by the phenol/guanidine isothiocyanate method, followed by DNAse I digestion, reverse transcription of $1 \mu \mathrm{g}$ of RNA and real-time PCR as reported earlier (TaqMan PCR, Applied Biosystems, Foster City, Calif., USA) [30]. All primers were designed using sequence information of the following GenBak accession numbers: NM_014590 (syncytin-1), NM 003643 (GCMa), AF105423 (ASCT2), V00573 (hPL) and M10277 
( $\beta$-actin). For analysis by TaqMan PCR, a specific fluorogenic oligonucleotide (probe) is necessary for detection, labeled with 6carboxy-fluorescein (FAM) at the $5^{\prime}$ end and 6-carboxy-tetramethyl-rhodamine (TAMRA) at the $3^{\prime}$ end.

The following primer sequences were applied: syncytin-1, sense 5'-CGTACCCATACTCGCCTGGTA-3', antisense 5' GGTTTTGGGCCGAGACCT-3', probe 5'-(FAM)-CCTATTTAATACCACCCTCACTGGGCTCCA-(TAMRA)-3'; GCMa, sense 5'-GAACCTGACGACTTTGATTC-3', antisense 5'-TGCTCCCCTTCAGGCTC-3', probe $5^{\prime}$-(FAM)-TCTGGAGGCACGACGGACGCTTTATA-(TAMRA)-3'; ASCT2, sense 5' -CCCCACTGAGGAAGGAAACCC-3', antisense 5'-TCTCAGAGGCGACCGTGGCA-3', probe $5^{\prime}$-(FAM)-TCAAACACTATCGGGGGCCCGCAGGG-(TAMRA)-3'; hPL, sense 5'-GGAAACGCAACAGAAATCCA-3', antisense 5'-GCCACGACTCGATGAGCA-3', probe $5^{\prime}$-(FAM)-TCTAGAGCTGCTCCGCATCTCCCTG-(TAMRA)$3^{\prime}$, and $\beta$-actin, sense $5^{\prime}$-GCGAGAAGATGACCCAGGATC-3', antisense 5'-CCAGTGGTACGGCCAGAGG-3', probe 5' CCAGCCATGTACGTTGCTATCCAGGC-(TAMRA)-3'.

Syncytin-1, GCMa, ASCT2 and hPL mRNA amounts were normalized to $\beta$-actin mRNA levels.

\section{Hormone Measurement}

To monitor syncytial cell differentiation, $\beta$-hCG was measured in the cell culture supernatants using an enzyme-linked immunosorbent assay kit (DRG International, Mountainside, N.J., USA) with a sensitivity of $1.0 \mathrm{mIU} / \mathrm{ml}$ and inter- and intraassay variation coefficients of less than $10 \%$ [14]

\section{Immunocytochemistry}

Syncytium formation was assessed immunocytochemically by the reduction of the amount of desmoplakin. Cells were cultured on culture slides, fixed with ice-cold methanol and incubated with a rabbit polyclonal antibody against desmoplakin (dilution 1:200). This was followed by an Alexa 488-conjugated goat antimouse IgG (dilution 1:250). Cell nuclei were labeled with DAPI as reported earlier [29]. Antibodies were obtained from Chemicon (Temecula, Calif., USA) or MoBiTec (Vienna, Austria). A BX60 microscope (Olympus Deutschland GmbH, Hamburg, Germany) and the software/camera system F-View II-Kamera (Soft Imaging System, Munster, Germany) were used for visual evaluation.

\section{Statistical Methods}

Data were analyzed using Prism 4.0 software (GraphPad, San Diego, Calif., USA). All values are given as means \pm 1 standard error of the mean. To compare the groups, statistical analysis was performed using the Mann-Whitney test or one-way ANOVA if appropriate. A p value $<0.05$ was considered to be significant.

\section{Results}

Gene Expression of GCMa, Syncytin-1 and ASCT2

First of all we investigated the time courses and peak gene expression of syncytin- 1 and its transcription factor GCMa, depending on the oxygen concentration and on 8-Br-cAMP or forskolin treatment. Under normoxic con- ditions, we found the highest gene expression of both syncytin-1 and GCMa in trophoblasts following $24 \mathrm{~h}$ of culture in the presence of 8-Br-cAMP, followed by a considerable decline after 48 and $72 \mathrm{~h}$ of cell culture (fig. 1A, B). A comparable time course but with lower peak mRNA amounts was found at $1 \% \mathrm{O}_{2}$ (fig. $\left.1 \mathrm{~A}, \mathrm{~B}\right)$. However, the overall peak GCMa gene expression in trophoblasts was observed after $48 \mathrm{~h}$ at 3 and $6 \% \mathrm{O}_{2}$, compared to $24 \mathrm{~h}$ at normoxia or severe hypoxia (fig. 1A). Peak syncytin-1 gene expression at 3 and $6 \% \mathrm{O}_{2}$ occurred after 24 and $48 \mathrm{~h}$ (fig. 1B), respectively. In addition, we investigated mRNA levels of the syncytin-1 receptor ASCT2. Gene expression of ASCT2 in trophoblasts was slightly higher in the presence of 8-Br-cAMP at 3 and $6 \% \mathrm{O}_{2}$ at 48 and $72 \mathrm{~h}$ than at 1 and $21 \% \mathrm{O}_{2}$ (fig. $1 \mathrm{C}$ ). Under severe hypoxia at $1 \% \mathrm{O}_{2}$ along with 8 -Br-cAMP treatment, we found a decline in ASCT2 gene expression after $48 \mathrm{~h}$ (fig. 1C).

We next focused on the effects of different oxygen levels on GCMa and syncytin-1 gene activity in the absence of 8-Br-cAMP or forskolin. In the absence of these stimuli, the highest GCMa and syncytin-1 mRNA levels were observed after incubation for $24 \mathrm{~h}$ at $6 \% \mathrm{O}_{2}$ (fig. $2 \mathrm{~A}$ ) and for $72 \mathrm{~h}$ at $3 \% \mathrm{O}_{2}$ (fig. 2C), whereas no differences were observed after $48 \mathrm{~h}$ of culture at 3,6 , and $21 \% \mathrm{O}_{2}$ (fig. 2B). As in cells stimulated with 8-Br-cAMP, for example, the effects of oxygen deprivation on GCMa and syncytin-1 gene expression in native trophoblasts were more pronounced at $1 \% \mathrm{O}_{2}(\mathrm{p}<0.05-\mathrm{p}<0.01$; fig. $2 \mathrm{~A}-\mathrm{C})$. In unstimulated trophoblasts, ASCT- $2 / \beta$-actin mRNA ratios were found constantly at $0.7-1.2$ at $24-72 \mathrm{~h}$ with no apparent trend (data not shown).

Moreover, we compared GCMa, syncytin-1 and ASCT2 gene activity in trophoblasts in the presence or absence of 8-Br-cAMP or forskolin for the various oxygen concentrations and incubation periods. Generally, incubation with $150 \mu \mathrm{M}$ 8-Br-cAMP at a particular oxygen level resulted in equal or higher GCMa and syncytin1 mRNA amounts in primary term human trophoblasts, compared to those stimulated with $100 \mu \mathrm{M}$ forskolin (table 1). In principle, the lowest mRNA amounts in response to cAMP stimuli were found at $1 \% \mathrm{O}_{2}$ (table 1).

\section{Placental Differentiation Markers $\beta$ - $h C G$ and $h P L$}

We measured hPL mRNA and $\beta$-hCG concentrations in the supernatants in order to focus on different parameters and to monitor syncytial differentiation parameters at the mRNA and protein level. As expected, stimulation with forskolin or 8-Br-cAMP led to a time-dependent increase in hPL mRNA and $\beta$-hCG concentrations in the supernatants of primary term human trophoblasts under 
Fig. 1. Gene expression of GCMa (A), syncytin-1 (B) and ASCT2 (C) normalized to $\beta$-actin in primary term human trophoblasts after incubation with $150 \mu \mathrm{M} 8-\mathrm{Br}-$ cAMP at normoxia $\left(21 \% \mathrm{O}_{2}\right)$ or different levels of hypoxia $\left(1,3\right.$ and $\left.6 \% \mathrm{O}_{2}\right)$ for different incubation periods (24, 48 and $72 \mathrm{~h}$ ). ${ }^{* *} \mathrm{p}<0.01,{ }^{* * *} \mathrm{p}<0.001$ versus unstimulated controls.
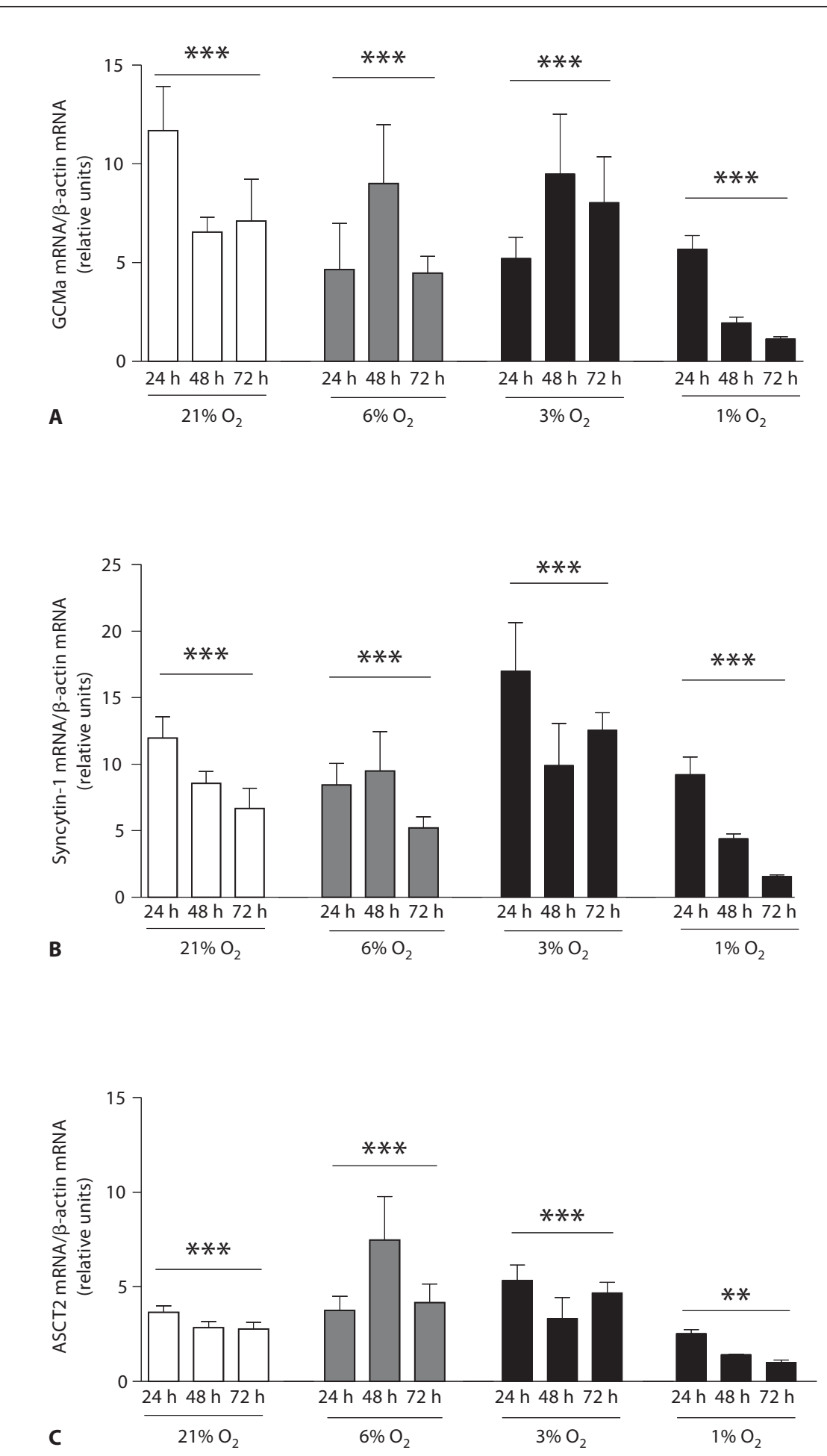


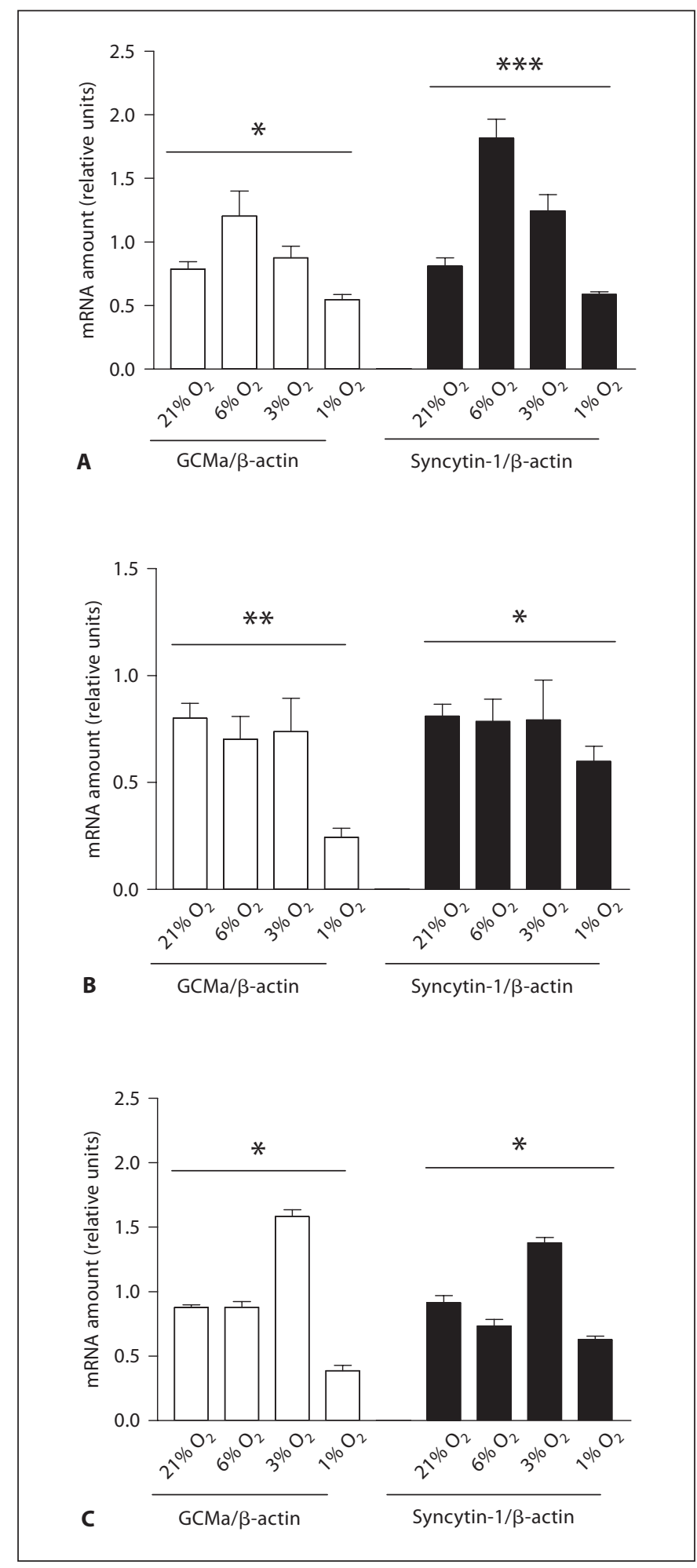

Fig. 2. Gene expression of GCMa and syncytin-1 normalized to

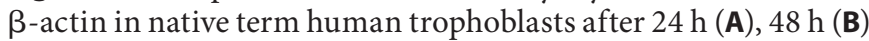
and $72 \mathrm{~h}(\mathbf{C})$ of culture at different oxygen levels $(21,6,3$ and $1 \%$ $\mathrm{O}_{2}$ ) in the absence of forskolin or 8-Br-cAMP. ${ }^{*} \mathrm{p}<0.05,{ }^{* *} \mathrm{p}<$ $0.01,{ }^{* * *} \mathrm{p}<0.001$.

Hypoxia-Induced Effects on Syncytin-1 and Cell Fusion normoxic conditions and at $6 \% \mathrm{O}_{2}$ (fig. $3 \mathrm{~A}, \mathrm{~B}$ ). Generally, hPL mRNA amounts peaked earlier (at $24 \mathrm{~h}$ ) compared to concentrations of $\beta$-hCG protein in the supernatants (72 h). When we compared the different oxygen levels, we found that peak hPL mRNA amounts were highest at $21 \%$ $\mathrm{O}_{2}$ in the presence of either forskolin or 8-Br-cAMP (fig. 3A) and lower under the various hypoxic conditions. Under the more severely hypoxic conditions of 1 and 3\% $\mathrm{O}_{2}$, hPL gene expression was reduced by $\geq 85 \%$ compared with the level at $21 \% \mathrm{O}_{2}$, in the presence or absence of either forskolin or 8-Br-cAMP. It is of interest that in the absence of cAMP stimuli, the highest hPL mRNA amount was found at $6 \% \mathrm{O}_{2}(\mathrm{p}<0.01$ vs. normoxic control; fig. 3A).

As expected, cAMP stimuli led to a time-dependent increase in $\beta$-hCG in cell supernatants under both normoxic conditions and $6 \% \mathrm{O}_{2}$. The highest $\beta$-hCG concentrations were found after $72 \mathrm{~h}$ at $21 \% \mathrm{O}_{2}$ (fig. $3 \mathrm{~B}$ ). In general, the lower the oxygen concentration in the environment, the lower the $\beta$-hCG secretion into the cell culture supernatant (fig. 3B). For example, incubation at $6 \% \mathrm{O}_{2}$ for $72 \mathrm{~h}$ led to a significantly higher $\beta$-hCG secretion into the cell culture supernatant than culture at 1 or $3 \% \mathrm{O}_{2}$ $(\mathrm{p}<0.05)$. Comparable findings, but with lower peak values, were obtained for shorter incubation periods (data not shown).

\section{Cell Fusion Processes}

After $24 \mathrm{~h}$ of cell culture at 21 or $6 \% \mathrm{O}_{2}$ in the absence of 8-Br-cAMP, desmoplakin immunostaining was carried out to demonstrate intact cell boundaries in primary trophoblasts (fig. 4A, B). The extent of cellular differentiation and, consequently, syncytial fusion after $72 \mathrm{~h}$ of cell culture was assessed qualitatively by desmoplakin immunostaining in relation to nucleic DAPI staining. In particular, reduced desmoplakin staining was found in cells following stimulation with cAMP agonists under normoxic conditions or $6 \% \mathrm{O}_{2}$ (fig. $4 \mathrm{C}-\mathrm{F}$ ). Cell fusion almost disappeared under severe hypoxia of $1 \% \mathrm{O}_{2}$, irrespective of 8 -Br-cAMP as a stimulus, as indicated by the persistence of desmoplakin immunostaining after $72 \mathrm{~h}$ (fig. $4 \mathrm{G}, \mathrm{H}$ ).

\section{Discussion}

We focused here on trophoblastic cell differentiation at different oxygen levels together with alterations of the gene expression pattern of syncytin-1 and GCMa in order to further elucidate disruptions of syncytiotrophoblast 
Table 1. Gene expression of GCMa, syncytin-1 and ASCT2 normalized to $\beta$-actin in primary term human trophoblasts with or without forskolin or 8-Br-cAMP at different oxygen concentrations and incubation periods

\begin{tabular}{|c|c|c|c|c|c|c|c|}
\hline & \multirow{2}{*}{$\begin{array}{l}\text { Oxygen } \\
\%\end{array}$} & \multicolumn{6}{|l|}{ Stimuli } \\
\hline & & $\begin{array}{l}\text { forskolin } \\
24 \mathrm{~h}\end{array}$ & $\begin{array}{l}8-\mathrm{Br}-\mathrm{cAMP} \\
24 \mathrm{~h}\end{array}$ & $\begin{array}{l}\text { forskolin } \\
48 \mathrm{~h}\end{array}$ & $\begin{array}{l}8-\mathrm{Br}-\mathrm{cAMP} \\
48 \mathrm{~h}\end{array}$ & $\begin{array}{l}\text { forskolin } \\
72 \mathrm{~h}\end{array}$ & $\begin{array}{l}\text { 8-Br-cAMP } \\
72 \mathrm{~h}\end{array}$ \\
\hline \multirow[t]{4}{*}{ GCMa/ $\beta$-actin } & 21 & $9.1 \pm 1.5^{* *}$ & $14.9 \pm 2.2^{* * *}$ & $5.7 \pm 0.9^{* *}$ & $8.2 \pm 0.8^{* * *}$ & $3.5 \pm 0.4$ & $7.9 \pm 1.7^{* *}$ \\
\hline & 6 & $4.2 \pm 1.0^{*}$ & $2.9 \pm 1.8$ & $1.8 \pm 0.3$ & $12.8 \pm 3.0^{* *}$ & $3.2 \pm 0.4^{* *}$ & $4.5 \pm 0.9^{* *}$ \\
\hline & 3 & $4.9 \pm 0.8^{* *}$ & $6.0 \pm 1.0^{* *}$ & $8.2 \pm 1.2^{*}$ & $12.9 \pm 3.0^{* *}$ & $3.7 \pm 1.3^{*}$ & $4.7 \pm 2.3^{* *}$ \\
\hline & 1 & $5.9 \pm 0.1^{* * *}$ & $10.4 \pm 0.7^{* * *}$ & $3.8 \pm 0.1^{*}$ & $8.0 \pm 0.3^{* * *}$ & $1.3 \pm 0.8^{*}$ & $1.7 \pm 1.0$ \\
\hline \multirow[t]{4}{*}{ Syncytin- $1 / \beta$-actin } & 21 & $7.4 \pm 1.1^{* * *}$ & $14.8 \pm 1.6^{* * *}$ & $5.0 \pm 0.4^{* * *}$ & $10.6 \pm 0.9^{* * *}$ & $0.5 \pm 0.3$ & $5.3 \pm 1.5^{* * *}$ \\
\hline & 6 & $4.6 \pm 0.2^{* *}$ & $4.6 \pm 3.0^{* *}$ & $0.8 \pm 1.2$ & $12.1 \pm 1.6^{* *}$ & $3.5 \pm 0.4$ & $7.7 \pm 0.8^{* * *}$ \\
\hline & 3 & $4.6 \pm 1.1$ & $13.7 \pm 3.6^{* * *}$ & $3.9 \pm 0.6$ & $12.5 \pm 3.2^{*}$ & $4.6 \pm 0.3^{* * *}$ & $8.6 \pm 1.3^{* * *}$ \\
\hline & 1 & $7.3 \pm 0.4^{*}$ & $16.9 \pm 1.3^{* * *}$ & $8.8 \pm 0.1^{* * *}$ & $6.6 \pm 0.4^{* * *}$ & $2.2 \pm 0.2$ & $2.3 \pm 0.1$ \\
\hline \multirow[t]{4}{*}{ ASCT $2 / \beta$-actin } & 21 & $2.1 \pm 0.1$ & $5.4 \pm 0.3^{* * *}$ & $1.3 \pm 0.1$ & $4.1 \pm 0.3^{* *}$ & $1.1 \pm 0.2$ & $2.9 \pm 0.4^{* *}$ \\
\hline & 6 & $1.0 \pm 0.1$ & $2.0 \pm 0.7^{*}$ & $0.4 \pm 0.0$ & $4.1 \pm 2.3^{* *}$ & $1.1 \pm 0.4$ & $2.3 \pm 1.0^{* *}$ \\
\hline & 3 & $1.1 \pm 0.3$ & $3.1 \pm 0.8^{* *}$ & $0.6 \pm 0.0$ & $2.0 \pm 1.1^{* *}$ & $0.9 \pm 0.0$ & $2.7 \pm 0.6^{* *}$ \\
\hline & 1 & $1.7 \pm 0.0$ & $6.6 \pm 0.2^{* * *}$ & $1.1 \pm 0.6$ & $2.7 \pm 1.4^{* *}$ & $0.8 \pm 0.2$ & $1.3 \pm 0.1$ \\
\hline
\end{tabular}

Values are given as the fold change in mRNA ratio following culture with either $100 \mu \mathrm{M}$ forskolin or $150 \mu \mathrm{M} 8$-Br-cAMP compared to controls. Data represent means \pm SEM of 3-5 separate experiments performed in triplicate. ${ }^{*} \mathrm{p}<0.05,{ }^{* *} \mathrm{p}<0.01,{ }^{* *} \mathrm{p}<0.001$.

formation. Basically, fusiogenic syncytin-1 is involved in human trophoblastic cell differentiation and, consequently, fusion [7]. The underlying processes in syncytiotrophoblast formation may comprise elements of the molecular machinery of early apoptosis, including the phosphatidylserine flip $[29,31]$. In a recent study, we were able to demonstrate cell-cell fusion along with antiapoptotic properties in a cell model of syncytin-1-transfected CHO cells [29].

Connexin 43, which exerts its main effects on gap junctional communication, e.g. in trophoblasts, is also a putative effector molecule $[14,21]$. The existence of these cell-to-cell channels may facilitate the fusion process directly.

It has been previously shown in vitro that mononuclear cytotrophoblasts differentiate rapidly within the first $48 \mathrm{~h}$ of culture [32]. Following an early increase, we observed a progressive decrease in syncytin-1 and GCMa transcripts after $48 \mathrm{~h}$ of cell culture, which may be indicative of a regulatory limitation of the fusion process. Along these lines, we found peak levels of hPL mRNA under normoxic conditions at $24 \mathrm{~h}$ and of $\beta$-hCG protein at $72 \mathrm{~h}$ of culture. In addition, we observed only minor changes in syncytin-1 receptor ASCT2 mRNA amounts for the cell culture conditions applied. Lower ASCT2 expression in BeWo cells has been described following in- cubation with forskolin for $48 \mathrm{~h}$ [15]. Membrane specialization accompanying cell-cell fusion events may last for more than $48 \mathrm{~h}$ in cell culture, depending on the trophoblastic cell type $[25,33]$. Forskolin-treated cells may demonstrate additional features compared to 8-Br-cAMPtreated cells.

Here we tested the effects of different oxygen levels on GCMa, syncytin-1 and ASCT2 transcription within a setting comparable to in vivo conditions as indicated by measurements of placental partial oxygen pressure [34]. The concentration of oxygen in early placentogenesis is assumed to be around $2.6 \% \mathrm{O}_{2}$, equivalent to approximately $18 \mathrm{~mm} \mathrm{Hg}$ [35]. Low placental oxygen concentrations may protect cytotrophoblasts from oxidative damage during the first trimester, when a high rate of DNA synthesis and proliferation is of vital importance [36]. Our data obtained for hypoxia of $\geq 3 \% \mathrm{O}_{2}(\geq 21 \mathrm{~mm} \mathrm{Hg}$ ) could represent this early period of placentogenesis with peak expression of syncytin-1 and GCMa along with the initiation of syncytium formation. After the remodeling of uterine spiral arteries from small resistance vessels to large capacitance arteries from the 12th-13th week of gestation on, increased levels of oxygen (e.g. $8.6 \% \mathrm{O}_{2}$ or $61 \mathrm{~mm} \mathrm{Hg}$ ) could be measured [37, 38]. A normoxic atmosphere $\left(21 \% \mathrm{O}_{2}, 150 \mathrm{~mm} \mathrm{Hg}\right)$ applied in the cell culture model is higher than the in vivo oxygen concentra- 
Fig. 3. Gene expression of hPL normalized to $\beta$-actin in term human trophoblasts after $24 \mathrm{~h}(\mathbf{A})$ and concentration of $\beta$-hCG in cell culture supernatants after $72 \mathrm{~h}$ of culture (B) at different oxygen levels in the presence or absence of $100 \mu \mathrm{M}$ forskolin or $150 \mu \mathrm{M} 8$-Br-cAMP as indicated. ${ }^{*} \mathrm{p}<$ $0.05,{ }^{* *} \mathrm{p}<0.01,{ }^{* * *} \mathrm{p}<0.001$.

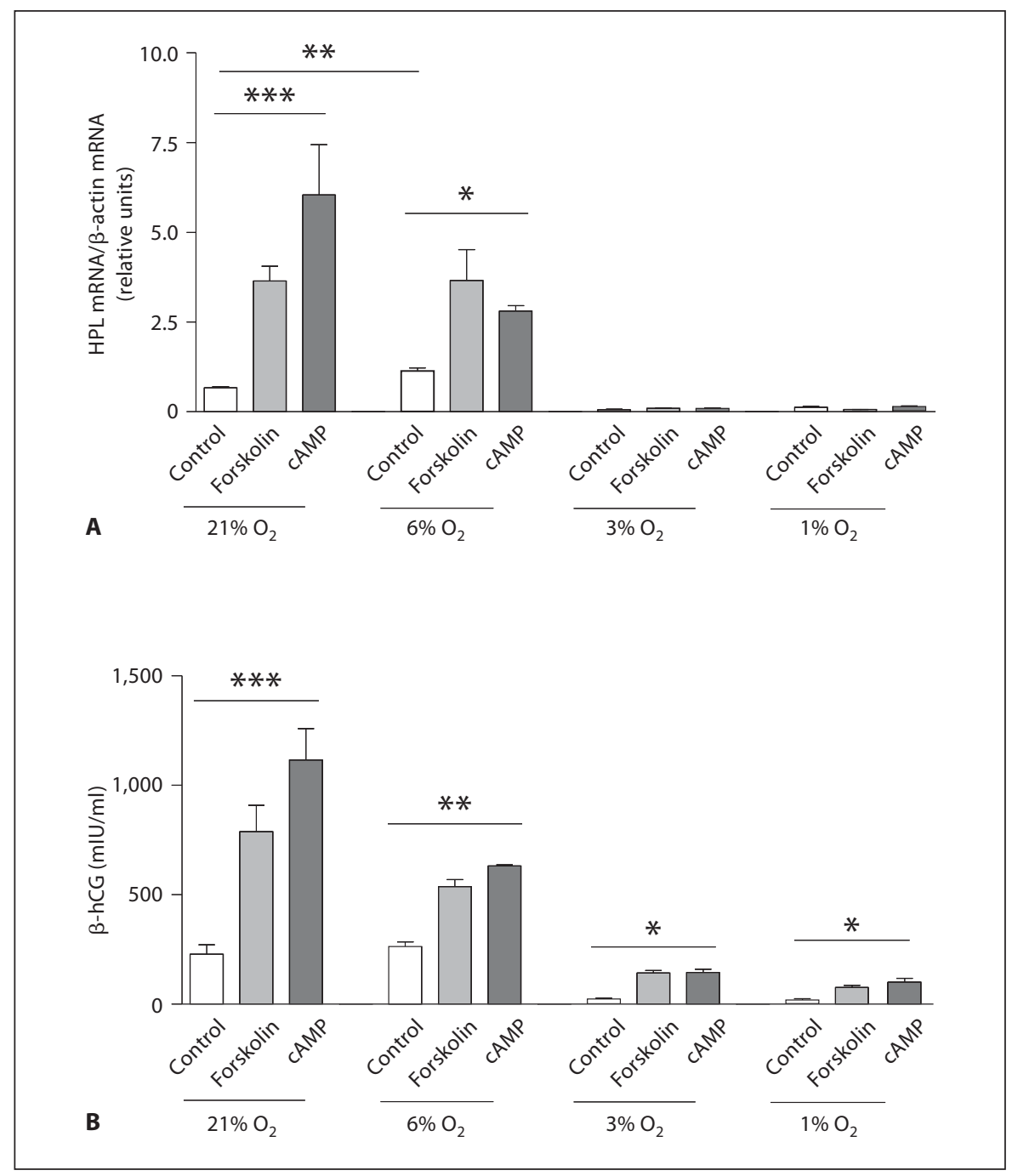

tion within the placenta at around $40 \mathrm{~mm} \mathrm{Hg}$ on average [39].

As indicated by the differentiation markers hPL and $\beta$-hCG, placental syncytial differentiation is a time-dependent process in the presence of oxygen (e.g. $\mathrm{pO}_{2} \geq 20$ $\mathrm{mm} \mathrm{Hg}$ ). A proliferative phenotype of trophoblastic cells, characterized by an increased mitotic rate, predominates under lower oxygen levels, such as $\leq 3 \%$, comparable to in vivo conditions in the first weeks of gestation $[4,36]$. Our data obtained at severe hypoxia also indicate an altered response of primary trophoblasts to cAMP stimuli at $1 \% \mathrm{O}_{2}$ compared with cell culture conditions with a higher oxygen tension.

The underlying mechanisms may comprise a reduction of gene expression of syncytin-1 and GCMa in a severe hypoxic atmosphere $\left(1 \% \mathrm{O}_{2}\right.$ or $\left.7 \mathrm{~mm} \mathrm{Hg}\right)$, with ten- tatively lower amounts of GCMa mRNA than syncytin-1 mRNA. Our results therefore support the essential role of syncytin-1 in the regulation of trophoblastic differentiation processes. A partially preserved gene expression, even in unfavorable environmental conditions, may be indicative of the regulatory effects of transcriptional factors other than GCMa. In principle, hypoxia does not facilitate an isolated pathway, and the effects of hypoxia may vary with the cell type and culture conditions. Oxygen-sensing pathways and transcription factors such as the basic helix-loop-helix PAS transcription factor hypoxia-inducible factor-1 (HIF-1) are among the adaptive responses of placental cells to a hypoxic atmosphere [35, 39]. HIF-1 also induces the gene expression of transforming growth factor $\beta 3$ during early placentation and maintains the proliferative capability of trophoblastic cells 



Fig. 4. Desmoplakin immunostaining of primary term human trophoblasts. Positive immunofluorescence, indicative of the presence of desmosomes, was observed after $24 \mathrm{~h}$ of culture at $21 \%$ $\mathrm{O}_{2}\left(\right.$ A) and $6 \% \mathrm{O}_{2}($ B). Reduced desmoplakin staining, comparable to cell-cell fusion processes, was found after $72 \mathrm{~h}$ of cell culture with $21 \% \mathrm{O}_{2}$ in the absence $(\mathbf{C})$ or presence of $150 \mu \mathrm{M}$ 8-Br-cAMP
(D) and after $72 \mathrm{~h}$ of culture with $6 \% \mathrm{O}_{2}$ in the absence (E) or presence of $150 \mu \mathrm{M} 8$-Br-cAMP (F). Under severe hypoxic conditions at $1 \% \mathrm{O}_{2}$, positive desmoplakin immunofluorescence was detected after $72 \mathrm{~h}$ of cell culture in the absence $(\mathbf{G})$ or presence of 150 $\mu \mathrm{M} 8$-Br-cAMP $(\mathbf{H})$ to drive cell fusion. Nuclei of cells were labeled with DAPI for blue fluorescence. 
[40]. Overexpression of HIF-1 and transforming growth factor $\beta 3$ in the placental tissue of pre-eclamptic women indicates altered trophoblastic differentiation processes in pre-eclampsia [40-42].

Essentially, under severe hypoxic conditions, alteration of syncytin-1 expression can be found in trophoblasts together with reduced cell-cell fusion, indicative of a predominance of a less differentiated phenotype. Moreover, the response of primary term human trophoblasts to cAMP stimuli as a major signaling molecule may be altered under severe hypoxic conditions. However, the coordination of trophoblastic differentiation and syncytialization, e.g. the interaction between GCMa and other transcription factors, must be further elucidated in order to gain more insight into the molecular basis of disordered placentogenesis. For this purpose, studies focusing on first-trimester cytotrophoblasts instead of term trophoblasts and also a three-dimensional cell culture model may be of additional value.

\section{Acknowledgements}

We are grateful to Tina Vogler and Elke Licha for excellent technical assistance and Patricia Schmid for valuable comments. This research was supported by the German foundation 'Das zuckerkranke Kind' (to I.K.).

\section{References}

1 Ananth CV, Vintzileos AM: Medically indicated preterm birth: recognizing the importance of the problem. Clin Perinatol 2008;8: 53-67.

2 Barden A: Pre-eclampsia: contribution of maternal constitutional factors and the consequences for cardiovascular health. Clin Exp Pharmacol Physiol 2006;33:826-830.

3 Gul A, Cebeci A, Aslan H, Polat I, Ozdemir A, Ceylan Y: Perinatal outcomes in severe preeclampsia-eclampsia with and without HELLP syndrome. Gynecol Obstet Invest 2005;59:113-118.

4 Soleymanlou N, Jurisica I, Nevo O, Ietta F, Zhang X, Zamudio S, Post M, Caniggia I: Molecular evidence of placental hypoxia in pre-eclampsia. J Clin Endocrinol Metab 2005;90:4299-4308.

5 Alsat E, Wyplosz P, Malassine A, Guibourdenche J, Porquet D, Nessmann C, EvainBrion D: Hypoxia impairs cell fusion and differentiation process in human cytotrophoblast, in vitro. J Cell Physiol 1996;168: 346-353.

6 Huppertz B, Kingdom J, Caniggia I, Desoye G, Black S, Korr H, Kaufmann P: Hypoxia favours necrotic versus apoptotic shedding of placental syncytiotrophoblast into the maternal circulation. Placenta 2003;24:181190.

7 Mi S, Lee X, Li X, Veldman GM, Finnerty H, Racie L, LaVallie E, Tang XY, Edouard P, Howes S, Keith JC Jr, McCoy JM: Syncytin is a captive retroviral envelope protein involved in human placental morphogenesis. Nature 2000;403:785-789.

8 Blond JL, Beseme F, Duret L, Bouton O, Bedin F, Perron H, Mandrand B, Mallet F: Molecular characterization and placental expression of HERV-W, a new human endogenous retrovirus family. J Virol 1999;73: 1175-1185.
9 Knerr I, Huppertz B, Weigel C, Dotsch J, Wich C, Schild RL, Beckmann MW, Rascher W: Endogenous retroviral syncytin: compilation of experimental research on syncytin and its possible role in normal and disturbed human placentogenesis. Mol Hum Reprod 2004;10:581-588.

10 Lee X, Keith JC Jr, Stumm N, Moutsatsos I, McCoy JM, Crum CP, Genest D, Chin D, Ehrenfels $\mathrm{C}$, Pijnenborg R, van Assche FA, Mi $S$ : Downregulation of placental syncytin expression and abnormal protein localization in pre-eclampsia. Placenta 2001;2:808-812.

11 Knerr I, Beinder E, Rascher W: Syncytin, a novel human endogenous retroviral gene in human placenta: evidence for its dysregulation in pre-eclampsia and HELLP syndrome. Am J Obstet Gynecol 2002;186:210-213.

12 Kudo Y, Boyd CA, Sargent IL, Redman CW: Hypoxia alters expression and function of syncytin and its receptor during trophoblast cell fusion of human placental BeWo cells: implications for impaired trophoblast syncytialisation in pre-eclampsia. Biochim Biophys Acta 2003;1638:63-71.

13 Chen CP, Wang KG, Chen CY, Yu C, Chuang $\mathrm{HC}$, Chen $\mathrm{H}$ : Altered placental syncytin and its receptor ASCT2 expression in placental development and pre-eclampsia. BJOG 2006; 113:152-158.

14 Knerr I, Schubert SW, Wich C, Amann K, Aigner T, Vogler T, Jung R, Dotsch J, Rascher W, Hashemolhosseini S: Stimulation of GCMa and syncytin via cAMP mediated PKA signaling in human trophoblastic cells under normoxic and hypoxic conditions. FEBS Lett 2005;579:3991-3998.

15 Kudo Y, Boyd CA: Changes in expression and function of syncytin and its receptor, amino acid transport system B(0) (ASCT2), in human placental choriocarcinoma BeWo cells during syncytialization. Placenta 2002; 23:536-541.
$16 \mathrm{Yu}$ C, Shen K, Lin M, Chen P, Lin C, Chang GD, Chen H: GCMa regulates the syncytinmediated trophoblastic fusion. J Biol Chem 2002;277:50062-50068.

17 Frendo JL, Olivier D, Cheynet V, Blond JL, Bouton O, Vidaud M, Rabreau M, Evain-Brion D, Mallet F: Direct involvement of HERVW Env glycoprotein in human trophoblast cell fusion and differentiation. Mol Cell Biol 2003;23:3566-3574.

18 Hashemolhosseini S, Wegner M: Impacts of a new transcription factor family: mammalian GCM proteins in health and disease. J Cell Biol 2004; 166:765-768.

19 Cronier L, Frendo JL, Defamie N, Pidoux G, Bertin G, Guibourdenche J, Pointis G, Malassine A: Requirement of gap junctional intercellular communication for human villous trophoblast differentiation. Biol Reprod 2003;69:1472-1480.

20 Malassine A, Cronier L: Involvement of gap junctions in placental functions and development. Biochim Biophys Acta 2005;1719: 117-124.

21 Frendo JL, Cronier L, Bertin G, Guibourdenche J, Vidaud M, Evain-Brion D, Malassine A: Involvement of connexin 43 in human trophoblast cell fusion and differentiation. J Cell Sci 2003;116:3413-3421.

22 Keryer G, Alsat E, Tasken K, Evain-Brion D: Cyclic AMP-dependent protein kinases and human trophoblast cell differentiation in vitro. J Cell Sci 1998;111:995-1004.

23 Beham A, Denk H, Desoye G: The distribution of intermediate filament proteins, actin and desmoplakins in human placental tissue as revealed by polyclonal and monoclonal antibodies. Placenta 1988;9:479-492.

24 Moe AJ: Placental amino acid transport. Am J Physiol 1995;268:C1321-C1331. 
25 Furesz TC, Smith CH, Moe AJ: ASC system activity is altered by development of cell polarity in trophoblast from human placenta. Am J Physiol 1993;265:C212-C217.

26 Knerr I, Weigel C, Linnemann K, Dotsch J, Meissner U, Fusch C, Rascher W: Transcriptional effects of hypoxia on fusiogenic syncytin and its receptor ASCT2 in human cytotrophoblast BeWo cells and in ex vivo perfused placental cotyledons. Am J Obstet Gynecol 2003;189:583-588.

27 Kliman HJ, Nestler JE, Sermasi E, Sanger JM, Strauss JF 3rd: Purification, characterization, and in vitro differentiation of cytotrophoblasts from human term placentae. Endocrinology 1986;118:1567-1582.

28 Schaiff WT, Bildirici I, Cheong M, Chern PL, Nelson DM, Sadovsky Y: Peroxisome proliferator-activated receptor-gamma and retinoid $\mathrm{X}$ receptor signaling regulate fatty acid uptake by primary human placental trophoblasts. J Clin Endocrinol Metab 2005;90: 4267-4275.

29 Knerr I, Schnare M, Hermann K, Kausler S, Lehner M, Vogler T, Rascher W, Meissner U: Fusiogenic endogenous-retroviral syncytin1 exerts anti-apoptotic functions in staurosporine-challenged $\mathrm{CHO}$ cells. Apoptosis 2007; 12:37-43.
30 Knerr I, Dachert C, Beinder E, Metzler M, Dotsch J, Repp R, Rascher W: Adrenomedullin, calcitonin gene-related peptide and their receptors: evidence for a decreased placental mRNA content in preeclampsia and HELLP syndrome. Eur J Obstet Gynecol Reprod Biol 2002;101:47-53.

31 Black S, Kadyrov M, Kaufmann P, Ugele B, Emans N, Huppertz B: Syncytial fusion of human trophoblast depends on caspase 8 . Cell Death Differ 2004;11:90-98.

32 Yang M, Lei ZM, Rao ChV: The central role of human chorionic gonadotropin in the formation of human placental syncytium. Endocrinology 2003;144:1108-1120.

33 Nelson DM, Smith SD, Furesz TC, Sadovsky Y, Ganapathy V, Parvin CA, Smith CH: Hypoxia reduces expression and function of system A amino acid transporters in cultured term human trophoblasts. Am J Physiol Cell Physiol 2003;284:C310-C315.

34 Rodesch F, Simon P, Donner C, Jauniaux E: Oxygen measurements in endometrial and trophoblastic tissues during early pregnancy. Obstet Gynecol 1992;80:283-285.

35 Caniggia I, Winter JL: Adriana and Luisa Castellucci Award lecture 2001. Hypoxia inducible factor-1: oxygen regulation of trophoblast differentiation in normal and preeclamptic pregnancies - a review. Placenta 2002;23(suppl A):S47-S57.

36 James JL, Stone PR, Chamley LW: The regulation of trophoblast differentiation by oxygen in the first trimester of pregnancy. Hum Reprod Update 2006;12:137-144.
37 Rajakumar A, Conrad KP: Expression, ontogeny, and regulation of hypoxia-inducible transcription factors in the human placenta. Biol Reprod 2000;63:559-569.

38 Jauniaux E, Watson AL, Hempstock J, Bao YP, Skepper JN, Burton G: Onset of maternal arterial blood flow and placental oxidative stress. A possible factor in human early pregnancy failure. Am J Pathol 2000;157:21112122.

39 Genbacev O, Zhou Y, Ludlow JW, Fisher SJ: Regulation of human placental development by oxygen tension. Science 1997;277:16691672.

40 Cowden Dahl KD, Fryer BH, Mack FA, Compernolle V, Maltepe E, Adelman DM, Carmeliet P, Simon MC: Hypoxia-inducible factors 1alpha and 2alpha regulate trophoblast differentiation. MolCell Biol 2005;25:1047910491.

41 Nishi H, Nakada T, Hokamura M, Osakabe Y, Itokazu O, Huang LE, Isaka K: Hypoxiainducible factor-1 transactivates transforming growth factor-beta 3 in trophoblast. Endocrinology 2004;145:4113-4118.

42 Rajakumar A, Doty K, Daftary A, Harger G, Conrad KP: Impaired oxygen-dependent reduction of HIF-1alpha and -2alpha proteins in pre-eclamptic placentae. Placenta 2003; 24:199-208. 